\title{
Foundations of Effective Classroom Management ${ }^{1}$
}

\author{
Kelsey M. Thornton, R. G. (Tre) Easterly III, and Ed Osborne ${ }^{2}$
}

This publication is intended to provide teachers with a framework for effective classroom management that will allow them to maximize their teaching effort and effectiveness with minimal disruptive student misbehavior.

\section{Introduction}

Classroom management can be challenging for all teachers. No single strategy can be implemented to effectively manage a classroom; a combination of several strategies is required. These strategies may come naturally to some teachers, while other teachers try to identify the strategies that work best for them and their students (Meador, 2019). No two classes are the same, yet every teacher should strive to meet the same overarching classroom management goals, as suggested by Bear (2010). These include (1) providing a safe, orderly, and positive learning environment and (2) developing student self-discipline and responsibility (as a long-term goal).

These principles are based on a Theory of Human Motivation developed by Abraham Maslow (1943). According to Maslow, individuals have basic and growth needs. If these needs are not met, the desire to satisfy the needs will intensify. This is critical for classroom management because if students are not given an opportunity to find belongingness and feel a sense of accomplishment in a positive way, they may seek to meet these needs by acting out or disengaging. However, teachers can provide structures to help students meet their needs and work towards self-discipline and responsibility.

\section{Nine Foundations of Effective Classroom Management}

The following foundations of effective classroom management will allow teachers to maximize their teaching effort and effectiveness with minimal disruptive student misbehavior.

\section{Maintain a positive attitude in your teaching.}

Students feed off their teacher's overall attitude. This may seem like a simple concept, but many teachers fail to purposely approach students with a positive attitude on a day-to-day basis. When teachers have a positive attitude, they are more likely to have students with positive attitudes. Students who receive encouragement and are praised for their efforts, instead of being criticized, will work harder to learn and meet teacher expectations (Meador, 2018).

\section{Set and maintain high expectations for your students.}

High expectations should be set for both student behavior and academics. If teachers expect their students to do well, they likely will (Bennett, 2020). Teachers who inconsistently reinforce performance and behavioral expectations, including classroom rules and student discipline, often struggle with classroom management. Maintaining consistency is the best approach for minimizing repeated disruptive behavior.

1. This document is AEC718, one of a series of the Department of Agricultural Education and Communication, UF/IFAS Extension. Original publication date February 2021. Visit the EDIS website at https://edis.ifas.ufl.edu for the currently supported version of this publication.

2. Kelsey M. Thornton, former master's student; R. G. (Tre) Easterly III, assistant professor; and Ed Osborne, professor, Department of Agricultural Education and Communication; UF/IFAS Extension, Gainesville, FL 32611.

The Institute of Food and Agricultural Sciences (IFAS) is an Equal Opportunity Institution authorized to provide research, educational information and other services

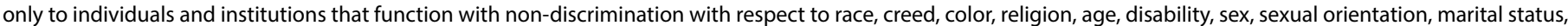

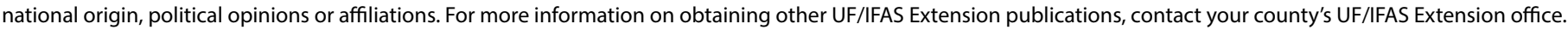
U.S. Department of Agriculture, UF/IFAS Extension Service, University of Florida, IFAS, Florida A \& M University Cooperative Extension Program, and Boards of County Commissioners Cooperating. Nick T. Place, dean for UF/IFAS Extension. 


\section{Effectively prepare for teaching.}

Highly effective teaching reduces classroom management problems (Meador, 2019). However, even on a typical school day, disruptions can occur. These disruptions can cause students to lose valuable in-class time. A prepared teacher can easily redirect students' attention back to meaningful learning after a disruption occurs. Teachers must be flexible in their teaching and develop a plan for dealing with the anticipated transitions and disruptions that might occur (Bennett, 2020). Aspects of effective preparation for teaching include the following:

- Place lesson objectives and resources in an area of the classroom where students can see them throughout the class period.

- Be prepared to redirect students when they get off task. Disruptions or misbehavior typically occur at the beginning of the lesson or class period, when topics or activities change, and at the conclusion of a lesson or class period.

- Greet students by name as they arrive to class each day to get a feel for their mood and temperament. Continue to use students' names while teaching.

- Engage students immediately with opening activities that require independent thinking and action.

- Defuse conflicts (student-to-student or student-toteacher) in the classroom with a series of steps, such as redirecting back to the learning activity, engaging in calm dialogue, temporarily relocating the student to a designated "cooling off" area, and speaking to the student in private. Teachers should use a nonthreatening tone in private talks with misbehaving students. As a last resort, consider removing the disruptive student from the classroom. Removing students from the classroom should not become routine practice.

\section{Establish strong rapport and relationships with students, parents, other teachers, administrators, and program supporters.}

Teachers who are well-liked and respected are likely to have fewer classroom management problems (Meador, 2019). This type of rapport is developed over time by investing in building relationships with students that extend beyond the classroom into extracurricular and community events. Take the time to learn about the individual interests of your students, including their likes and dislikes. Taking an interest in students' interests helps develop positive teacherstudent relationships (Meador, 2018, 2019).

\section{Deliver high-quality teaching for the full class or lab period.}

Teachers must develop high-quality lessons that are both interactive and engaging. A classroom full of engaged students is less likely to have classroom management problems (Bennett, 2020). Instructional teaching that encourages academic engagement and on-task behavior usually includes the following:

- instructional material that students find educationally relevant;

- a sequential order of instructional events that are logically related to skill development at the students' instructional level;

- frequent opportunities for students to respond;

- guided practice; and

- immediate feedback.

\section{Be consistent, fair, and calm when dealing with disrup- tive student behavior.}

Teachers must consistently and respectfully treat all students the same. When students feel they or other students in the classroom are being treated unfairly, discipline problems can follow (Bennett, 2020). When disruptive behavior occurs, remain calm and avoid overreacting out of frustration. If emotions are heightened, step away from the situation (unless immediate action is required for the safety of you and your students) until you can address it in a calm manner. Making a snap, harsh, or emotional decision can create an appearance of negligence on your part (Meador, 2019).

\section{Use classroom and lab routines.}

Discipline problems generally occur when students become disengaged (Meador, 2019). To keep students focused, teachers need to utilize classroom routines to help students know what to expect and how to engage in your class or lab. Each period of time in the classroom, no matter how short, should be planned. Predictable teacher routines include opening activities, which ease transitions into class, checks for understanding, and closing activities. If structured correctly, predictable student routines enhance independent work, team activities, lab activities, and group work (Bennett, 2020). 


\section{Organize the physical space (classroom and lab) for effective and safe learning.}

The physical environment of the classroom contributes to instruction and helps maintain desirable student behavior (Bennett, 2020). As part of a good classroom management plan, the physical arrangement of furniture, resources (including technology), and supplies should be organized in ways that:

- ease traffic flow, minimize distractions, and provide easy access to students;

- assist with transitions between various classroom and lab activities;

- support quality student interactions for specific classroom and lab activities;

- ensure adequate supervision of all areas; and

- contain clearly designated areas for staff and students.

\section{Be caring and demanding in your teaching.}

Most students will respond positively to a structured learning environment (Meador, 2019). Demonstrate through your words and actions that you have students' best interests in mind, while holding them accountable for their behavior and engagement by consistently reinforcing expectations. When addressing student misbehavior, provide specific feedback that reminds students of expectations and indicates how and why their behavior is unacceptable. In addition to helping students learn content knowledge and skills, effective teachers help students develop social skills, self-discipline, and responsibility (Meador, 2018).

\section{Summary}

Teachers must develop their own unique classroom management plan based on the physical space in their classroom and lab, lesson content and learning activities, and classroom dynamics - all aligned with performance and behavioral expectations. The nine foundations of effective classroom management presented in this publication support pursuit of the two overarching goals of effective classroom management: providing an effective, safe learning environment and developing student self-discipline and responsibility. Novice and experienced teachers alike must continuously practice good classroom management in order to reduce student behavior problems and maximize student learning and development.

\section{References}

Bear, G. (2010). Discipline: Effective school practices. National Association of School Psychologists. http://apps. nasponline.org/resources-and-publications/books-andproducts/samples/HCHS3_Samples/S4H18_Discipline.pdf

Bennett, C. (2020, January 21). 7 ways to take control of your classroom to reduce student misbehavior. ThoughtCo. https://www.thoughtco.com/ classroom-management-reduce-student-discipline-7803

Maslow, A. (1943). A theory of human motivation. Martino Fine.

Meador, D. (2018, March 12). Helpful classroom management strategies every teacher should try. ThoughtCo. https://www.thoughtco.com/ helpful-classroom-management-strategies-3194626

Meador, D. (2019, May 13). Classroom strategies for improving behavior management. ThoughtCo. https:// www.thoughtco.com/classroom-strategies-for-improvingbehavior-management-3194622 